\title{
On the Life Cycle of Spirillum japonicum
}

\author{
by Narumi WATANABE*
}

Received June 2, 1959

Since the life cycle of Azotobacter was studied by Löhnis and Smith ${ }^{1}$ ), many investigations mainly on those of bacilli have been carried out, but no reports on Spirillum except the recent ones of Williams's $\left.{ }^{2,3}\right)$. The following paper by the author is an attempt to describe the results of the study of the life cycle of halophilic Spirillum japonicum ${ }^{4}$ ) in a liquid medium.

\section{Method}

Spirillum japonicum grows well both on medium No. 1 and No. 2 at $22^{\circ}$. The cells obtained by liquid culture were mainly stained by the vital-staining method and observed under the microscope. Löffler's methylene blue solution diluted twice to thrice was used for staining and found very effective. Spirillum can live and keep moving in the dye for some time after it is stained. The method of flagellumstaining after Sugahara and Nishizawa adopted in this experiment proved successful. Carbol fuchsin solution as second solution is highly efficient to examine the minute structure. In this experiment, Ziehl's carbol fuchsin solution was sometimes used besides methylene blue solution, but it did not indicate the inner structure. Even the electron microscopic observation gave no satisfactory results. The reasons may be: 1). The cells of bacteria are so large that their contents immediately shrink due to desiccation in the vacuum-room. 2). The cell is too thick for the electron microscope to show the inner structure.

\section{Results}

1. Formation of conjunction capsule

In fresh culture the bacteria are very motile and reveal their typical spiral forms. The spiral cells divide through transverse fission like other bacteria. Young vegetative cells possess protoplasm which can be stained homogeneously by methylene blue solution, with fine unstained granules running obliquely to the long axis. These fine granules are not stained even by carbol fuchsin solution, so it may be assumed that they are not protoplasm but part of the cell membrane (Fig. 1. $\times 1350$ ).

The aerobic nature of this kind of bacteria brings about a turbid layer of about $1-1.5 \mathrm{~cm}$. thick under the surface of the medium. In $40-48$ hours culture fission becomes less active and stained granules are seen in the cell. At this stage each organism located on the surface of the medium is observed growing a capsule at the end like a cap. It may be appropriate to call the capsule "conjunction capsule" (Fig. 2 . $\times 1100$ ). As the flagella grow out of the protoplasm, the dot observed on the flagella and located a little distance away from the pole is assumed to be the crossing point of the capsule and the flagella (Fig. 3. $\times 1350$ ). As soon as a capsule begins to form, the spiral movement becomes slow while the cell starts vibrating.

\section{Radiate conjunction}

The cell with a capsule gathers each other and conjoin at the capsule, and a

* Biological Institute, Faculty of Education, Chiba University, Chiba, Japan. 
number of cells thus united take a radiate form $($ Fig. $4 \mathrm{a} \& 4 \mathrm{~b} . \times 1350)$. The number of uniting organisms gradually increases up to about forty. An unstained space is noticed where these cells join each other, which may indicate the existence of some capsules that can not stained by the flagellum-staining. Considering that the flagella remain unchanged in the center of the cells which are closely united at the poles as the conjunctive action proceeds, it is assumed that flagella take no part in the radiate arrangement (Fig. 5. shown by flagellum-staining. $\times 1350$ ). Then a number of radiate forms are observed macroscopically to gather into a large mass floating like lumps of cloud in the medium (Fig. 6. $\times 550$ ), and sink down to the bottom by slight stimulus.

Then the adhesive power of the organisms by which the radiate arrangement is maintained is so strong that they do not separate when artificially stimulated, for instance, by a stream of water passing between the deck glass and the slide glass or by a pressure given over the deck glass (Fig. $7 . \times 550$ ). The radiate arrangement is preserved for a long time in the preparation fixed with formalin (Fig. 8. stained with carbol fuchsin solution after fixation. $\times 1100$ ).

One giant organism about twice as thick as the normal one is always attached to the center of a radiate form. (Fig. 8, Fig. 9a \& 9b. $\times 1350$ ) Later this giant cell comes to contain some large stained grains which may derive from the protoplasmic substance (Fig. 10. $\times 1350$ ). The giant cell, which the writer would like to name "stalk cell" provisionally, is supposed to keep the radiate form stable in the medium.

The central part of the radiate form is too intensely stained to admit a glimpse into its structure (Fig. 9). Even the electron microscopic observation does not reveal the details of the radiate arrangement. Therefore, we are obliged to define the significance of the radiate arrangement by its subsequent behaviors. At the anaphase of the radiate arrangement, every one of the organisms except the giant one becomes thin while all the protoplasm in every cell transfers to the middle of the cell. Thus both the stained and unstained parts are seen in the same cell (Fig. 11. $\times 550)$.

\section{Exocyst formation}

The radiate arrangement becomes looser and looser and finally it breaks up into free organisms making a slow spiral movement. A protuberance is made on the lateral side of the middle part of some organisms (Fig. 12. $\times 1350$ ). The incipient protuberance membrane is so fragile as to release the contents by slight stimulus. The contents released from the cell are the protoplasm containing the stained granules. After the release, the mother cell becomes empty (Fig. 13. $\times 1350)$.

As the globular protuberance grows bigger, it absorbs the greater part of the protoplasm and the stainable granules in the mother cell. (Fig. 14a \& 14b. $\times 1350$ ) When the exocyst is formed, the organism sinks to the bottom of the medium and then the exocyst is separated from its mother cell. All these processes need 5-6 days to complete after the inoculation. After the completion of the exocyst, the mother cell takes a loose spiral form containing several stained grains arranged in a row. Each stained grains consists of several stained granules (Fig. 15. $\times 1100$ ). When an organism becomes extinct or destroyed, the grains are scattered in the medium and disappear (Fig. 16a \& 16b. $\times 1350$ ). The stalk cell still retains its giant shape after the loosening of the radiate arrangement and its future course is unknown.

\section{Endocyst formation}

Apart from the bacterial cells arranged in a radius, there is a group of very motile cells in the turbid layer of the medium. Often these cells are each shaped 
like one wave as the result of fission. The middle part of the cell swells up and most of protoplasm migrates to this part, that is, it takes as a whole a somewhat twisted "V" or " J" shape (Fig. 17a \& 17b. $\times 1350$ ). The protoplasm of the cell then works to make a globular endocyst. At this time a very small portion of the protoplasm remains at both extremities, or the basal granules of the flagella. The flagellum is found firmly sticking to the cell even after the organism has lost its power to move and comes down to lie still at the bottom of the medium (Fig. 18. shown by flagellum-staining). A full-grown endocyst is often discovered remaining in the mother cell (Fig. 19. $\times 1350$ ). The absence of a reflective membrane distinguishes the endocyst from the endospore of other bacteria. Compared with the exocyst, the endocyst is larger and reveals the details of its inner structure, when it is stained.

\section{Germination of cysts}

The protoplasm is reorganized in both exocyst and endocyst before germination. It is homogeneous at first, but as the time of germination approaches, it begins to form a spiral structure (Fig. 20. $\times 1350$ ). When inoculated in the medium, the exocyst develops into an oval shape in four to five hours and the germ tube begins to emerge from one of the poles (Fig. 21. $\times 1350$ ). And then it develops into a normal spiral shape. The mature endocyst separates itself from the mother cell and begins to germinate in the medium like the exocyst. The mother cell is left empty (Fig. 22. $\times 1350)$.

\section{Discussion}

Kishitani and Sumiyoshi ${ }^{5}$ ) found the radiate form in purple bacteria and considered this phenomenon as the intermediate form between the conjugation and symplasma asserted by Löhnis. Watanabe ${ }^{6}$ ) also found the same phenomenon in Rhodobacillus palustris. Smith $^{7}$ ) who advanced the theory of the conjugation of bacteria, reported that two bacilli make a pair end to end in Bacteroides fundulformis. Lederberg ${ }^{8}$ ) observed the conjugal pairing in Escherichia coli. Williams ${ }^{2}$ ) observed the fusion of two spirilla in Spirillum lunatum and stated as follows. "The establishment of sexual fusion in Escherichia coli by Lederberg in 1947, based on genetical studies of the exchange of character in mutants of this organism, has not been confirmed by morphological evidence of conjugation or cellular fusion in the bacteria ". Apart from microscopical observation, Lederberg ${ }^{9}$ ) and Holloway ${ }^{10}$ ) reported the genetic re-combination in detail: the former on Escherichia coli and the latter on Pseudomonas aeruginosa. Lederberg ${ }^{11}$ ) referred also to the sex compatibility.

Potthoff ${ }^{12}$ ) maintained the presence of a conjugation process formed on the lateral wall in the fusion of Rhodospirillum photometricum and named it the "bridge." Watanabe ${ }^{6}$ ) also insisted on the presence of a cojugating capsule at the cell end of Rhodobacillus palustris.

Dimitroff ${ }^{13}$ ) named the equivalent of a reproductive body in Spirillum virginianum "coccoid body". Cayton and Preston ${ }^{14}$ ) took a photograph of the globular shape of Spirillum manucuniense. The reproductive body, or the "large body," which is formed as the lateral or terminal bud in Proteus vulgaris was reported by Stempen and Hutchinson $\left.{ }^{15}, 16\right)$. Williams held the similar view of Spirillum and she named the body formed on the point of fusion "microcyst", from which vegetative cell germinates.

Now, the writer wants to discuss the problem of the cellular fusion on which Williams reported. She asserted that two spirilla entwined with each other to fuse. 

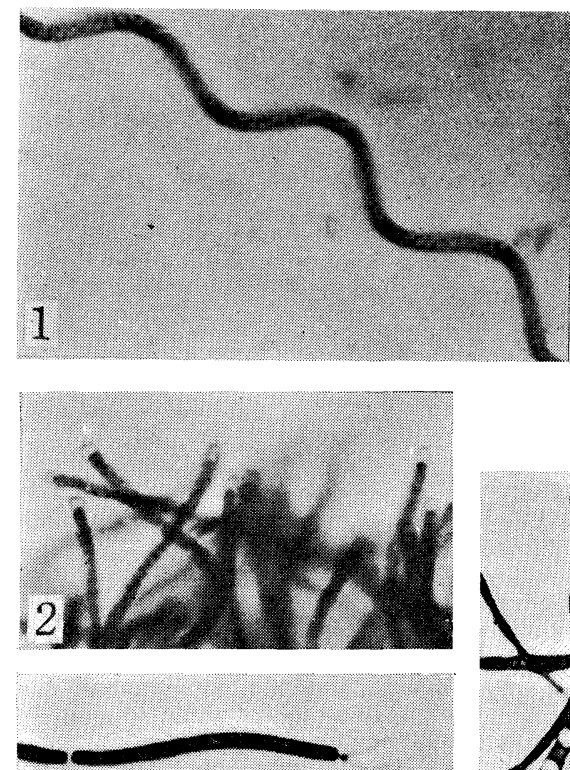

3
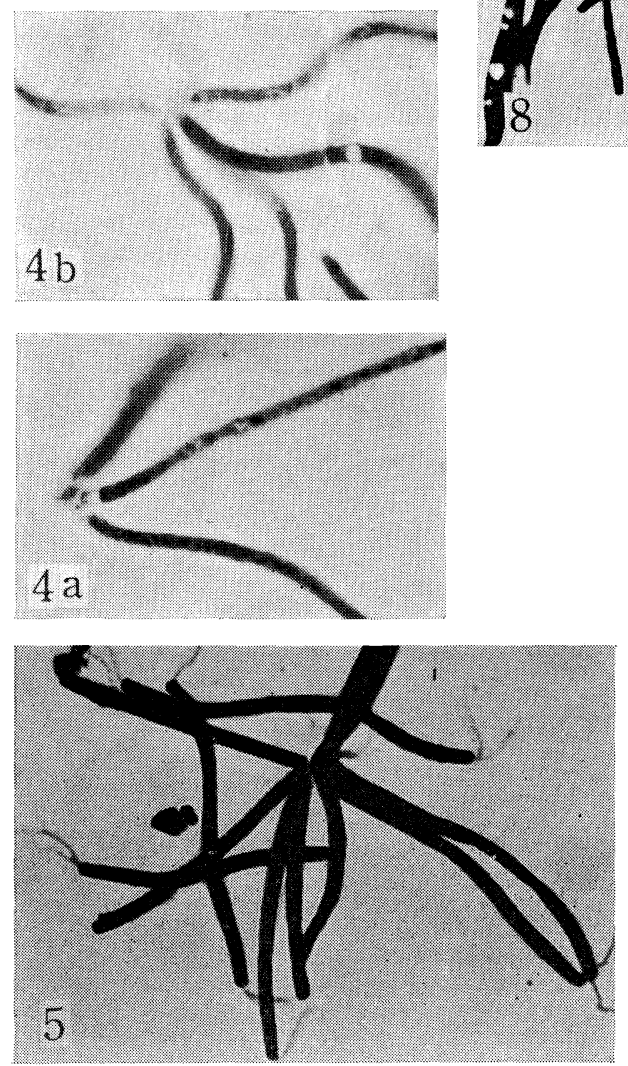
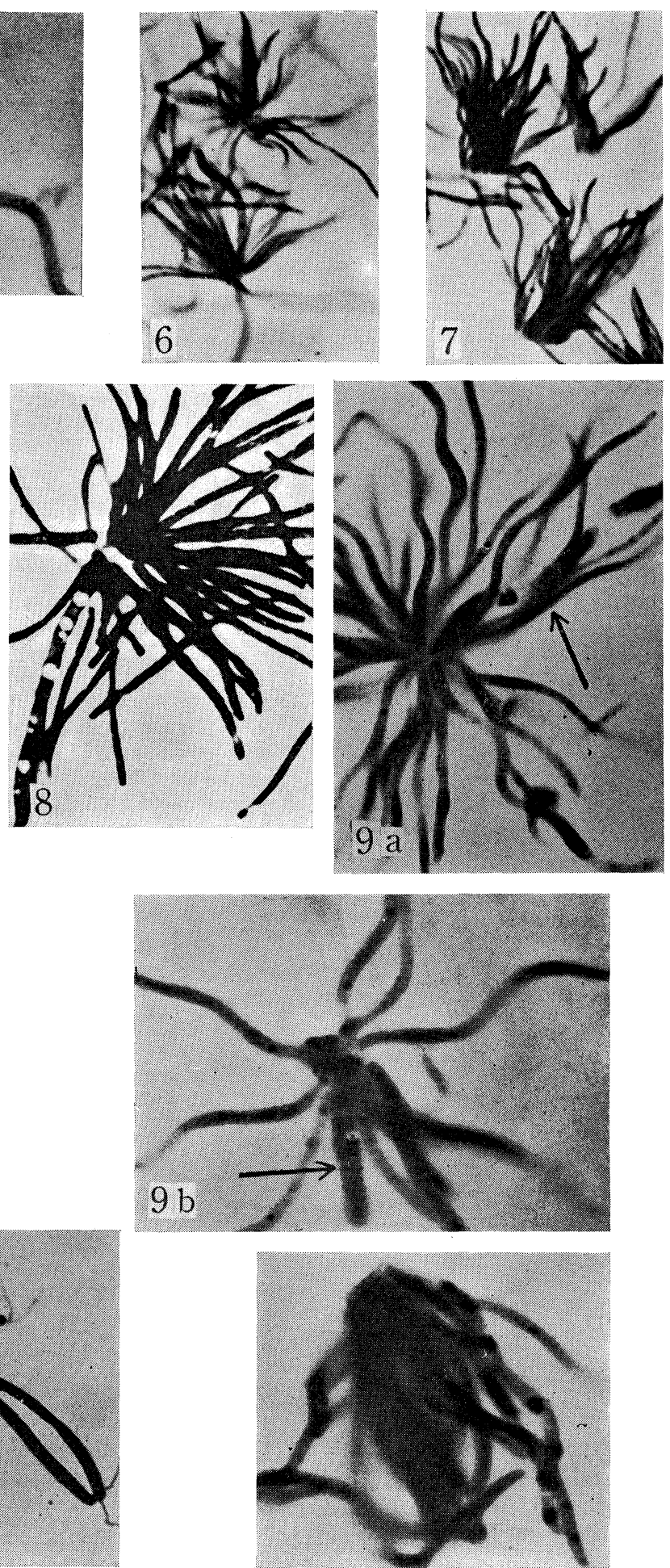


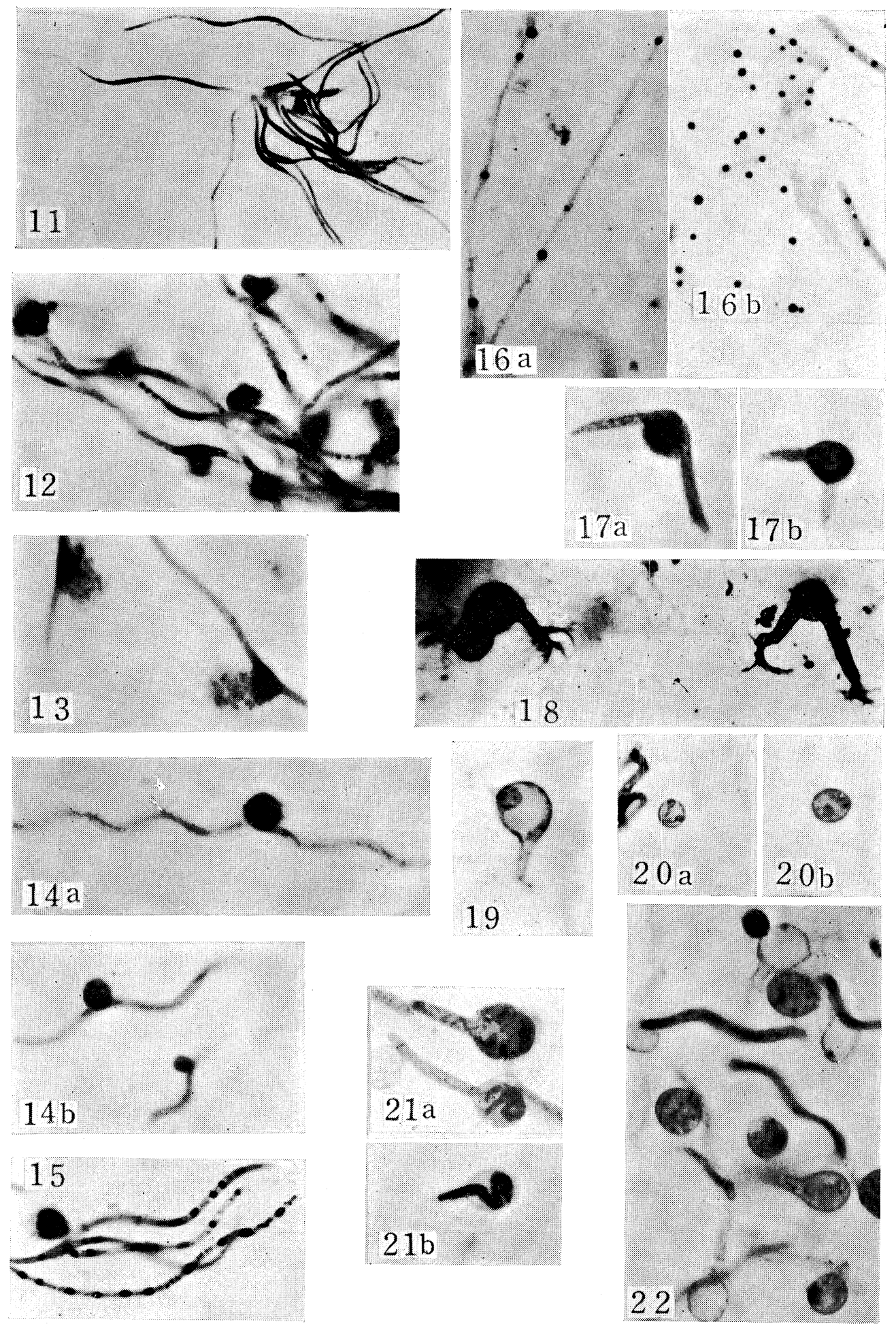


But, it is obvious that an "entwined shape" can not be observed, if two spirilla are arranged in exact parallel. An entwined shape can be only observed when one spiral cell enters the other so that the two cells having the same convolution may entwine each other. And separation is only possible by going convoluting forward or backward. Therefore, it is maintained that the cellular fusion is difficult to be effected only by the attraction of a motile organism to the motionless one. Moreover, it follows that the fusion must be made at every spiral wave of the two entwined spirilla. Consequently, it is very doubtful that there is only one point of fusion between the two entwined organisms. Williams's statement as to the number of fusion points and of microcyst is very vague.

According to the writer's observation, it is not clear whether or not the migration of the protoplasm in Spirillum japonicum takes place between the cells at the time of the radiate arrangement. But the facts that the radiate arrangement is very stable and that the exocyst is formed with part of the protoplasm may indicate the presence of a sort of conjugation among the spirilla.

Williams ${ }^{3}$ ) observed some chromatin granules arranged in a row in the bacterial cells of Spirillum sinosum and Sp. anulus. Yuasa and Tanaka reported the presence of some nuclear materials in a granular state in young Spirillum sp. and in the state of some longitudinal rods at its later stage of development. The grains which appear only in the vegetative cells of Spirillum japonicum after the exocyst formation have a shape very similar to that nuclear substance of different dominations given by those investigators cited above. Judging from its behaviors, however, the writer has some doubts in admitting any of them as the true nuclear substance.

\section{Summary}

1. When Sprillum japonicum is cultured in a medium, it has two kinds of vegetative cells: one type has many conspicuous undulations and forms an exocyst, the other is shorter in length and looks like a rod-bacteria having a slight undulation and forms an endocyst.

2. The organisms of the first type with "conjunction capsule" growing at the extremities form a radiate arrangement. This phenomenon is the cellular fusion which should be assumed as a kind of conjugation.

Vegetative cell

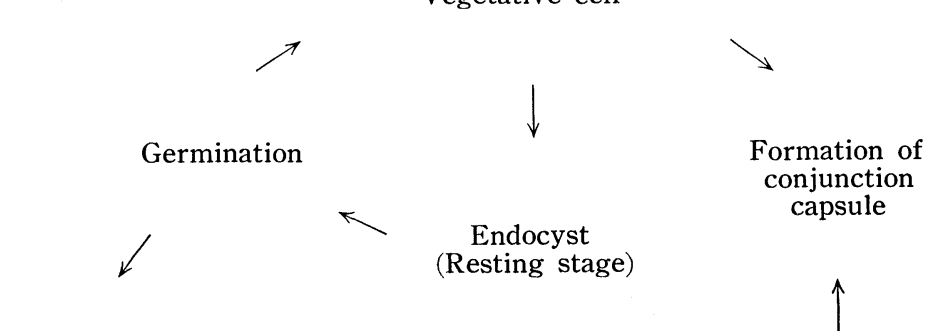

Exocyst

(Resting stage)
Radiate arrangement

(A kind of conjugation)

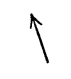

Growth of protuberance

Free organism 
3. The protuberance absorbing the protoplasm of each fused cell develops into a globular exocyst. Both the endocyst and the exocyst are deposited motionless in the medium as precipitate. The protoplasm in resting stage in the cyst displays itself as the spiral structure before germination. A new organism grows out of the cyst as the unipolar germination.

4. The life cycle of Spirillum japonicum is indicated in the diagram.

\section{References}

1) Löhnis, F. and Smith, N. R., Journ. Agr. Res., 6: 675 (1916). 2) Williams, M. A. and Rittenberg, S. C., J. Gen. Microbiol. 15: 205 (1956). 3) Williams, M. A., Nuclear phenomena in Spirillum species. (1957) (Unpublished, a dessertation presented to the University of Southern California) 4) Watanabe, N., Bot. Mag. Tokyo 72: 77 (1959). 5) Kishitani, T. and Sumiyoshi, T., Jour. Scie. Hiroshima Univ. Series B, Div. 2. 3: 1 (1939). 6) Watanabe, N., Bull. Fac., Education, Chiba Univ. 1: 1 (1952). 7) Smith, W. E., Jour. Bact. 47: 417 (1944). 8) Lederberg, J., Jour. Bact. 71: 497 (1956). 9) —, Genetics 32: 505 (1947). 10) Hollway, B. W., J. Gen. Microbiol. 13: 572 (1955). 11) Lederberg, J., Genetics 37: 720 (1952). 12) Potthoff, H., Centr. f. Bakt. 2 Abt. 55: 9 (1922). 13) Dimitroff, V. T., Jour. Bact. 12: 19 (1926). 14) Cayton, H. R. and Preston, N. W., J. Gen. Microbiol. 12: 519 (1955). 15) Stempen, H. and Hutchinson, W. G., Jour. Bact. 61: 321 (1951). 16) —, 1954. Sex in bacteria. Evidence from morphology. In sex in microorganism. Washington D. C. American Association for the Advancement of Science. (Cited in Williams's report.) 17) Yuasa, A. and Tanaka, K., Sci. Papers, College of General Education, Univ. Tokyo 8: 175 (1958).

$\begin{array}{cc}\text { 摘 } & \text { 要 } \\ \text { Spirillum japonicum } & \text { の生活環について } \\ \text { 渡 辺 成 美 }\end{array}$

液休堵地上に堷養した好㙁性螺旋菌の一種 Spirillum japonicum の生活環を観察した。この目的には レフラー氏メチレン青液の 2 3 倍稀秋液を使用し，生体染色飞良好な結果を得た。観察の結果栄養細胞 には, 形態的に二型が存在することが明らかになつた.すなわち, 第一型は多数螺旋形で一種の接合と見 做される繁殖法を行なうものであり，第二型はやや長桿状の単螺旋形で無性的繁殖を行なうものである.

前者の繁殖法は，いわゆる放射接着であり，二分法の減退した螺旋菌多数が集合し，菌の一端をもつて 放射状に配列して強固に接着する。この際各菌端に生じた接着膜囊が重大な役割をなするのとみられ，菌 端にある鞭毛は何等の関与を示さない，接着により菌端間に原形質の移動が生ずるか否か形態的には不明 であるが，それ以後の菌の行動から，一種の接合現象であると推察される．放射配列から解放された菌体 には，内部原形質の中央部移動に伴ない菌側に隆起が生ずる。この隆起は母体の原形質を吸収し外生包囊 飞生長する. 外生包囊は完成後, 培盖基中に沈澱物となり, 静止期に入り, 耐久性を獲得する.

後者, すなわち無性繁殖型は栄養細胞の原形質の濃縮によつて内生包霆の形成の久を行なう。迎動性を 失なつた母体内から内生包孁は完成後脱出する.内生包囊は良好な染色性や形態から, 明らか飞他の細菌 群にみられる内生芽胞とは区別することができる.

内生，外生包囊とも均質染色性の原形質を有するが，その再編制により，原形質は包囊内に扔いて螺旋 形構造を示すようになる。新培地飞接種された包囊は発芽を行ない新做体に生育する．以上の镜察事実よ り, Spirillum japonicum の生活環に有性, 無性の繁殖法が刑行する可能性を主張した。（千葉大学 教 育学部 生物学教室) 